\title{
Peertechz
}

\section{Hepatic involvement in COVID 19 infection}

\section{Jayanta Paul*}

Consultant Gastroenterologist, Department of Gastroenterology, Desun Hospital and Heart Institute, Kolkata 700107, India
Received: 18 November, 2020

Accepted: 10 December, 2020

Published: 12 December, 2020

*Corresponding author: Dr. Jayanta Paul, MBBS, MD DNB (Gastroenterology), Consultant Gastroenterologist, Department of Gastroenterology, Desun Hospital and Heart Institute, Kolkata 700107, India, Tel: (+91) 8348984088; E-mail: dr.jayantapaul@gmail.com

Keywords: COVID 19; Liver; Hepatic involvement

https://www.peertechz.com

\section{Abstract}

Background: Severe Acute Respiratory Distress Syndrome Coronavirus -2 (SARS -CoV-2) outbreak is a significant public health threat since December 2019. Lung is the most common organ involved by COVID 19 followed by gastrointestinal tract and liver. This review article discusses hepatic involvement and monitoring in this outbreak.

Methods: Recently published studies from PubMed, Red Cross, and Copernicus were reviewed to prepare this review article.

Conclusions: Hepatic involvement is common in COVID 19 infection and it is the second most common organ involved after lung. Most of the hepatic involvements are mild and self limiting. However close monitoring is required.

\section{Introduction}

Coronavirus disease 2019 (COVID-19), is a highly infectious respiratory virus that emerged in Wuhan, China and has posed a serious threat to human health worldwide since December 2019. coronavirus disease 2019 (COVID-19), is a highly infec-tious respiratory virus that emerged in Wuhan, China and has posed a serious threat to human health worldwide since December 2019. coronavirus disease 2019 (COVID-19), is a highly infec-tious respiratory virus that emerged in Wuhan, China and has posed a serious threat to human health worldwide since December 2019.

Corona virus disease 2019 (COVID-19) is a highly infectious respiratory virus that is a serious threat to human health worldwide since December 2019. It has been declared public health emergency of international concern by the World Health Organization (WHO). It is firmly a disease of droplet transmission and contact transmission however it may be an airborne disease in poorly ventilated and closed area. Majority of COVID-19 affected patients are asymptomatic but most common presentations of symptomatic patients include fever and respiratory symptoms, such as cough, shortness of breath and dyspnoea. This virus enters through angiotensin converting enzyme II (ACE2)-expressing cells and this cell is expressed not only in lung, but also seen in gastrointestinal system. Patients who experience gastrointestinal (GI) symptoms (nausea, vomiting, or diarrhea) are more likely to suffer from severe pneumonia. Three-stage classification system is proposed for COVID19 infection: stage I (early infection), stage II (pulmonary phase), and stage III (hyperinflammation phase) $[1,2]$. After lung involvement, liver appears to be the second organ involved [3,4].

\section{Manifestation of liver injury}

Hepatic injury in mild COVID-19 infection is often transient and can return to normal without any special management. Overall $39.6 \%$ to 53\% COVID 19 infected patients show elevation of alanine Aminotransferase (ALT) and aspartate Aminotransferase (AST) levels [5,6]; however hyperbilirubinemia or clinically detected jaundice is seen in only $11 \%$ to $18 \%$ patients $[7,8]$. Few studies also reported a decrease in serum albumin, suggesting hepatic synthetic function impairment in COVID 19. Gamma-glutamyl transferase (GGT) is elevated in $54 \%$ patients, whereas only $1.8 \%$ of patients $(1 / 56)$ showed elevated alkaline phosphatase (ALP) level [9]. Prevalence of AST elevation is higher in men $(66 \%)$ than women (35\%) [10] and Probability of hepatic injury increases with older age [11].

\section{Mechanisms of liver involvement}

Currently, the underlying mechanisms for hepatic injury 
in patients with COVID-19 are still unclear however following mechanism of hepatic injury has been described.

First: ACE2 receptors in the liver are expressed mainly in cholangiocytes $(60 \%$ of cells), minimally expressed in hepatocytes ( $3 \%$ of cells) $[12,13]$ and presence of these receptors, together with the local effects of systemic inflammation seem to be the main mechanisms involved in the onset of liver damage in COVID-19 patients.

Second: Secondary to drugs used in COVID 19 treatment. Antiviral medications (lopinavir and ritonavir), acetaminophen, steroids, hydroxychloroquine and azithromycin have been used in some patients and may cause hepatotoxicity to various degrees. Presence of hypoxic state increases hepatotoxic potential of these drugs results in liver injury and elevate hepatic enzymes [14].

Third: Immune-mediated inflammation in COVID-19 infected patients may be the contributing factor of hepatic injury. Elevated plasma levels of cytokine and other inflammatory substances, such as interleukin-1 (IL-1), IL-6, and tumor necrosis factor results in cytokine storm in some patients, and may cause multiorgan failure and severe elevation of liver enzymes [15]. Use of remdesivir also can elevate liver enzymes [16].

Fourth: High levels of positive end expiratory pressure that can cause hepatic congestion by increasing right atrial pressure and impeding venous return may be a possible aetiology of hepatic injury in COVID 19 patients.

Fifth: Presence of pre-existing liver disease is also a contributing factor of elevated liver injury [17] or acute on chronic liver failure in COVID 19 infected patients. Liver cirrhosis patients are more susceptible to infections due to their systemic immunocompromised status [18]. Therefore, preventing infection with SARS-CoV-2 is of utmost importance.

\section{Histopathology}

The histology only showed moderate microvascular steatosis and mild lobular and portal activity. Pathological analysis of hepatocytes from patients who died from COVID-19 shows there is no viral inclusion in the liver [19].

\section{Monitoring}

According to the recent AASLD guidelines, regular liver function should be monitored in all hospitalized COVID-19 patients, in particular in those treated with remdesevir or tocilizumab, irrespective of baseline value of liver function test result [20].

\section{Management}

Till now there is no specific treatment for COVID 19 infection and no guidelines for management of hepatic injury in COVID-19 patients. The key is in prevention, that is, to help patients to avoid chances of being infected by SARS-CoV-2. High risk populations such as elderly population, patients with end stage liver disease and liver transplant recipients require close monitoring. There is no need of specific treatment for patients with mild abnormalities in liver function tests, however close monitoring is required. However, when severe liver damage occurs, liver protective drugs have usually been given to such patients in our unit. Avoidance of non-steroidal anti-inflammatory drugs is recommended.

\section{Conclusion}

Hepatic involvements in COVID-19 infected patients are common which can be due to direct effect of COVID-19 on hepatocytes and cholangiocytes, adverse effect of antiviral medications used for this infection, immune-mediated inflammation and high levels of positive end expiratory pressure. Pre-existing liver disease has to be excluded. In most of the cases hepatic involvement is self limiting but close monitoring is required.

\section{References}

1. Gui M, Song W, Zhou H, Xu J, Chen S, et al. (2017) Cryo-electron microscopy structures of the SARS-CoV spike glycoprotein reveal a prerequisite conformational state for receptor binding. Cell Res 27: 119-129. Link: https://go.nature.com/3gxeBQh

2. Siddiqi HK, Mehra MR(2020) COVID-19 illness in native and immunosuppressed states: a clinical-therapeutic staging proposal. J Heart Lung Transplant 39 405-407. Link: https://bit.ly/2JPNR1C

3. Li J, Fan JG (2020) Characteristics and Mechanism of Liver Injury in 2019 Coronavirus Disease. J Clin TransI Hepatol 8: 13-17. Link: https://bit.ly/33YljJ6

4. Bangash MN, Patel J, Parekh D (2020) COVID-19 and the liver: little cause for concern. Lancet Gastroenterol Hepatol 5: 529-530. Link: https://bit.ly/2JGQYZR

5. Shi H, Han X, Jiang N, Cao Y, Alwalid O, et al. (2020) Radiological findings from 81 patients withCOVID-19 pneumonia in Wuhan, China: a descriptive study. Lancet Infect Dis 20: 425-434. Link: https://bit.ly/340fNqj

6. Yang $X, Y u Y, X u$ J, Shu $H, X i a ~ J$, et al. (2020) Clinical course and outcomes of critically illpatients with SARS-CoV-2 pneumonia in Wuhan, China: a singlecentered,retrospective, observational study. Lancet Respir Med 8: 475-481. Link: https://bit.ly/39ZeqMG

7. Chen N, Zhou M, Dong X, Qu J, Gong F, et al. (2020) Epidemiological and clinica characteristics of 99 cases of 2019 novel coronavirus pneumonia in Wuhan China: a descriptive study. Lancet 395: 507-513. Link: https://bit.ly/3qLdqBJ

8. Guan WJ, Ni ZY, Hu Y, Liang W, Ou C, et al. (2020) Clinical Characteristics of Coronavirus Disease 2019 in China. N Engl J Med 382: 1708-1720. Link: https://bit.ly/372DZu2

9. Zhang C, Shi L, Wang FS (2020) Liver injury in COVID-19: management and challenges. Lancet Gastroenterol Hepatol 5: 428-430. Link: https://bit.ly/3gyo360

10. Fan Z, Chen L, Li J, Cheng X, Yang J, et al. (2020) Clinical Features of COVID 19-Related Liver Functional Abnormality. Clin Gastroenterol Hepatol 18: 1561 1566. Link: https://bit.ly/2Kekdmk

11. Feng G, Zheng KI, Yan QQ, Rios RS, Targher G, et al. (2020) COVID-19 and Liver Dysfunction: Current Insights and Emergent Therapeutic Strategies. Clin Transl Hepatol 8: 18-24. Link: https://bit.ly/3gxvZ7t

12. Qi F, Qian S, Zhang S, Zhang Z (2020) Single cell RNA sequencing of 13 human tissues identify cell types and receptors of human corona viruses. Biochem Biophys Res Commun 526: 135-140. Link: https://bit.ly/3gE74iL 
13. Hamming I, Timens W, Bulthuis ML, Lely AT, Navis G, et al. (2004) Tissue distribution of ACE2 protein, the functional receptor for SARS corona virus. A first step in understanding SARS pathogenesis. J Pathol 203: 631-637. Link: https://bit.ly/3n54SDr

14. Li Y, Xiao SY (2020) Hepatic involvement in COVID-19 patients: Pathology, pathogenesis, and clinical implications. J Med Virol 92: 1491-1494. Link: https://bit.ly/37SP5Rx

15. Zhang Y, Zheng L, Liu L, Zhao M, Xiao J, et al. (2020) Liver impairment in COVID-19 patients: A retrospective analysis of 115 cases from a single centre in Wuhan city, China. Liver Int 40: 2095-2103. Link: https://bit.ly/34105tg

16. The COVID-19 Investigation Team. First 12 patients with coronavirus disease 2019 (COVID-19) in the United States. Link: https://bit.ly/373gi53
17. Ji D, Qin E, Xu J, Zhang D, Cheng G, et al. (2020) Non-alcoholic fatty liver diseases in patients with COVID-19: A retrospective study. J Hepatol 73: 451 453. Link: https://bit.ly/3oliSDh

18. Strnad P, Tacke F, Koch A, Trautwein C (2017) Liver - guardian, modifier and target of sepsis. Nat Rev Gastroenterol Hepatol 14: 55-66. Link: https://bit.ly/3n7Z8J1

19. Xu Z, Shi L, Wang Y, Zhang J, Huang L, et al. (2020) Pathological findings of COVID-19 associated with acute respiratory distress syndrome. Lancet Respir Med 8: 420-422. Link: https://bit.ly/3qGBHZr

20. Fix OK, Hameed B, Fontana RJ, Kwok RM, McGuire BM, et al. (2020) Clinical Best Practice Advice for Hepatology and Liver Transplant Providers During the COVID-19 Pandemic: AASLD Expert Panel Consensus Statement. Hepatology 72: 287-304. Link: https://bit.ly/3n3ptll
Discover a bigger Impact and Visibility of your article publication with

\section{Peertechz Publications}

\section{Highlights}

* Signatory publisher of ORCID

* Signatory Publisher of DORA (San Francisco Declaration on Research Assessment)

* Articles archived in worlds' renowned service providers such as Portico, CNKI, AGRIS, TDNet, Base (Bielefeld University Library), CrossRef, Scilit, J-Gate etc.

* Journals indexed in ICMJE, SHERPA/ROMEO, Google Scholar etc.

- OAI-PMH (Open Archives Initiative Protocol for Metadata Harvesting)

* Dedicated Editorial Board for every journal

- Accurate and rapid peer-review process

* Increased citations of published articles through promotions

* Reduced timeline for article publication

Submit your articles and experience a new surge in publication services

(https://www.peertechz.com/submission).

Peertechz journals wishes everlasting success in your every endeavours.

Copyright: (c) 2020 Paul J. This is an open-access article distributed under the terms of the Creative Commons Attribution License, which permits unrestricted use distribution, and reproduction in any medium, provided the original author and source are credited. 